\title{
Allometric models for estimating biomass, carbon and nutrient stock in the Sal zone of Bangladesh
}

\author{
Hossain Mahmood (1), \\ Mohammad RH Siddique ${ }^{(1)}$, \\ Liam Costello ${ }^{(2)}$, \\ Luca Birigazzi ${ }^{(3)}$, \\ SM Rubaiot Abdullah (1), \\ Matieu Henry ${ }^{(3)}$, \\ Baktiar Nur Siddiqui ${ }^{(4)}$, \\ Tariq Aziz ${ }^{(4)}$, \\ Sayed $\mathrm{Ali}^{(4)}$, \\ Abdullah Al Mamun ${ }^{(4)}$, \\ Mofizul IK Forhad ${ }^{(5)}$, \\ Mariam Akhter ${ }^{(4-6)}$, \\ Zaheer Iqbal ${ }^{(4)}$, \\ Falgoonee Kumar Mondol ${ }^{(6)}$
}

\begin{abstract}
Allometric models are commonly used to estimate biomass, nutrients and carbon stocks in trees, and contribute to an understanding of forest status and resource dynamics. The selection of appropriate and robust models, therefore, have considerable influence on the accuracy of estimates obtained. Allometric models can be developed for individual species or to represent a community or bioregion. In Bangladesh, the nation forest inventory classifies tree and forest resources into five zones (Sal, Hill, Coastal, Sundarbans and Village), based on their floristic composition and soil type. This study has developed allometric biomass models for multi-species of the Sal zone. The forest of Sal zone is dominated by Shorea robusta Roth. The study also investigates the concentrations of Nitrogen, Phosphorus, Potassium and Carbon in different tree components. A total of 161 individual trees from 20 different species were harvested across a range of tree size classes. Diameter at breast height (DBH), total height $(\mathrm{H})$ and wood density (WD) were considered as predictor variables, while total above-ground biomass (TAGB), stem, bark, branch and leaf biomass were the output variables of the allometric models. The best fit allometric biomass model for TAGB, stem, bark, branch and leaf were: In (TAGB) $=-2.460$ $+2.171 \ln (\mathrm{DBH})+0.367 \ln (\mathrm{H})+0.161 \ln (\mathrm{WD}) ; \ln ($ Stem $)=-3.373+1.934 \ln$ $(\mathrm{DBH})+0.833 \ln (\mathrm{H})+0.452 \ln (\mathrm{WD}) ; \ln ($ Bark $)=-5.87+2.103 \ln (\mathrm{DBH})+$ $0.926 \ln (\mathrm{H})+0.587 \ln (\mathrm{WD}) ; \ln ($ Branch) $=-3.154+2.798 \ln (\mathrm{DBH})-0.729 \ln$ $(\mathrm{H})-0.355$ In (WD); and In (Leaf) $=-4.713+2.066$ In (DBH), respectively. $\mathrm{Nu}$ trients and carbon concentration in tree components varied according to tree species and component. A comparison to frequently used regional and pantropical biomass models showed a wide range of model prediction error (35.48 to $85.51 \%$ ) when the observed TAGB of sampled trees were compared with the estimated TAGB of the models developed in this study. The improved accuracy of the best fit model obtained in this study can therefore be used for more accurate estimation of TAGB and carbon and nutrients in TAGB for the Sal zone of Bangladesh.
\end{abstract}

Keywords: Common Model, Forest Inventory, Phytomass, Tropical Forest

\section{Introduction}

Allometric models are commonly used for estimating forest biomass (Picard et al. 2015). The models use mathematical functions that relate tree biomass with easily measurable tree variables such as diameter at breast height $(\mathrm{DBH})$, total height $(\mathrm{H})$ and wood density (WD - Sileshi 2014). Allometric equations can be developed for individual species or multiple species covering local, regional or pan-tropical scale. Species specific allometric models should logically provide a greater level of accuracy at a given location (Ketterings et al. 2001) to as-
(1) Forestry and Wood Technology Discipline, Khulna University, Khulna (Bangladesh); (2) School of Ecosystem and Forest Sciences, The University of Melbourne, Victoria 3010 (Australia); (3) Food and Agriculture Organization, Rome (Italy); (4) Bangladesh Forest Department, Dhaka (Bangladesh); (5) Bangladesh Forest Research Institute, Chittagong (Bangladesh); (6) Food and Agriculture Organization, Dhaka (Bangladesh)

@ Hossain Mahmood (mahmoodhossain@hotmail.com)

Received: Feb 10, 2018 - Accepted: Nov 10, 2018

Citation: Mahmood H, Siddique MRH, Costello L, Birigazzi L, Abdullah SMR, Henry M, Siddiqui BN, Aziz T, Ali S, Al Mamun A, Forhad MIK, Akhter M, Iqbal Z, Mondol FK (2019). Allometric models for estimating biomass, carbon and nutrient stock in the Sal zone of Bangladesh. iForest 12: 69-75. - doi: 10.3832/ifor2758-011 [online 2019-01-24]

Communicated by: Tomás Vrska sist the assessment of biomass dynamics, net primary productivity, nutrient cycling and budgeting for research purpose (Mahmood et al. 2008, Litton 2008). However, equations developed from small sample sizes may misrepresent the broader population and reduce the accuracy of results (Sileshi 2014). Regional and pan-tropical allometric models consider multiple species collectively defined by a climatic or geophysical association. Capturing species variability within such models has been overlooked in some notable examples (Brown 1997, Chave et al. 2005), while other models have addressed species variability with an additional variable such as wood density (Nelson et al. 1999, Chave et al. 2014). At local or sub-regional scale, the use of allometric biomass models for multiple species within a particular forest types can provide robust results while avoiding the frequently used pan-tropical or regional biomass models which are likely to be based on broader, more generalized suite of sample species (Brown et al. 1989, Brown \& Lugo 1992, Brown 1997, Chave et al. 2005, 2014, 


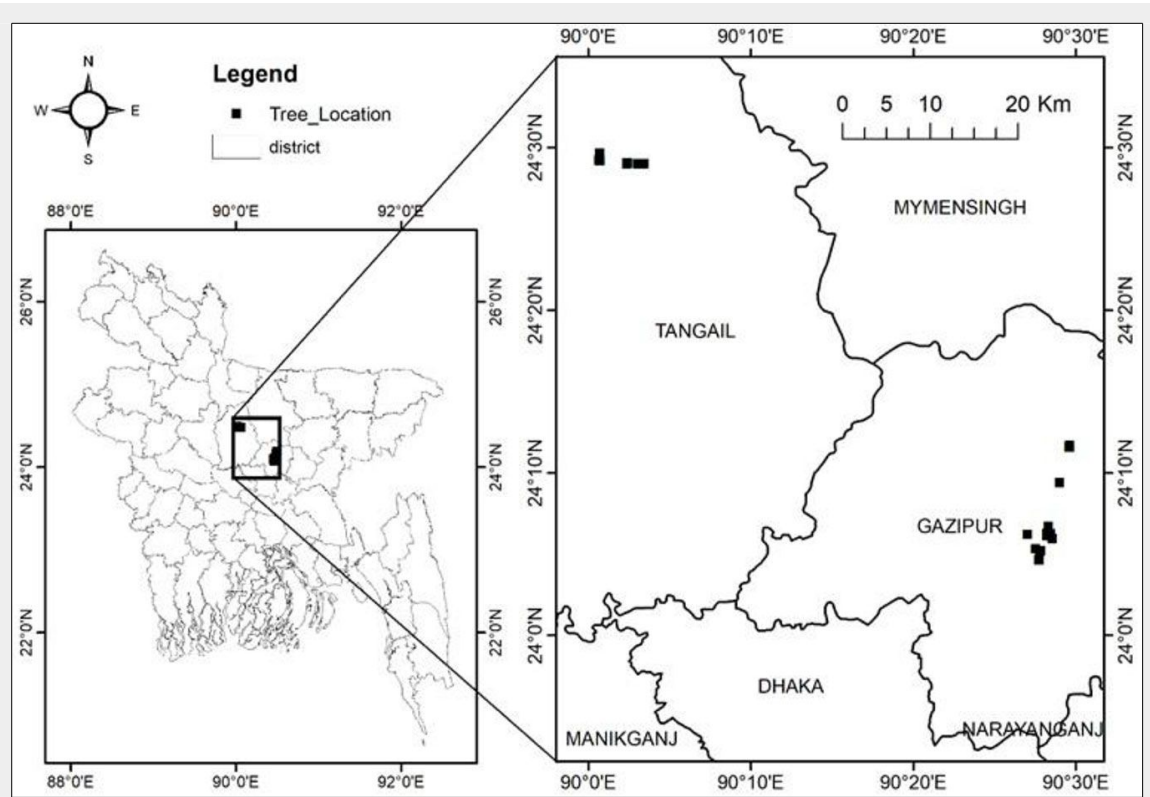

Fig. 1 - Location of study area in the Sal zone of Bangladesh.

Maulana et al. 2016, Nam et al. 2016).

Forests in Bangladesh have been actively managed for over 100 years (Iftekhar \& Saenger 2008). Indeed, sixteen inventories have been carried out in different forests types at different scales since 1960. Over this period, the objectives of forest monitoring have evolved from a focus on volume for timber resources to biomass for carbon related values. The National Forest and Tree Resources Assessment (NFA) in 2007 was the first country-wide inventory to measure tree biomass (FD 2017). In this assessment, biomass was calculated according to the Brown \& Lugo (1992) method using a generalized volume model,

Tab. 1 - Species and families of the sampled individuals in this study.

\begin{tabular}{|c|c|}
\hline Family & Species \\
\hline Anacardiaceae & Mangifera indica \\
\hline Combretaceae & $\begin{array}{l}\text { Terminalia arjuna } \\
\text { Terminalia bellerica }\end{array}$ \\
\hline Dipterocarpaceae & Shorea robusta \\
\hline Elaeocarpaceae & Elaeocarpus serratus \\
\hline Fabaceae & $\begin{array}{l}\text { Acacia auriculiformis } \\
\text { Acacia mangium } \\
\text { Albizia procera }\end{array}$ \\
\hline Lamiaceae & Tectona grandis \\
\hline Malvaceae & Grewia microcosm \\
\hline Moraceae & $\begin{array}{l}\text { Artocarpus } \\
\text { heterophyllus }\end{array}$ \\
\hline Myrtaceae & $\begin{array}{l}\text { Psidium guajava } \\
\text { Syzygium cumini }\end{array}$ \\
\hline Oxalidaceae & Averrhoa carambola \\
\hline Phyllanthaceae & Phyllanthus emblica \\
\hline Rhamnaceae & Ziziphus mauritiana \\
\hline Rutaceae & $\begin{array}{l}\text { Aegle marmelos } \\
\text { Citrus grandis } \\
\text { Zanthoxylum rhetsa }\end{array}$ \\
\hline Sapindaceae & Litchi chinensis \\
\hline
\end{tabular}

wood density and a biomass expansion factor $(A G B=$ volume over bark $\times$ wood density $\times$ biomass expansion factor), with an average wood density of $0.57 \mathrm{t} \mathrm{m}^{-3}$ and a biomass expansion factor of 6 to represent the tropical Asia (FD 2007).

Similarly, carbon stock in the Sundarbans mangrove forest was estimated using the pan-tropical allometric biomass models of Chave et al. (2005) and Komiyama et al. (2005) during 2009 to 2010 (Rahman et al. 2015). Tree species and their DBH, height and wood density ranges of pan-tropical models are not similar to the species available in different zones of Bangladesh. These generalized models sometimes fail to capture both variations in forest type (Chave et al. 2005, Litton 2008) and diversity of the natural vegetation communities, which range from mangrove forest in south-west, to tall tropical forests in the hilly areas in the east, and Sal (Shorea robusta Roth) dominated areas on inland terraced soils (FD 2017). Relying on pan-tropical models across such distinct structural forest types may distort estimates of biomass and carbon in the tropical forests (Van Breugel et al. 2011, Manuri et al. 2014). For these reasons, initiatives to develop local allometirc models in Bangladesh have been undertaken (Mahmood et al. 2016).

The Bangladesh Forest Department has formalized the stratification of its forest areas into to five distinct zones: Sal, Hill, Sundarbans, Coastal and Village to represent different forest types (BFD 2016). The zones are defined by their relative climatic and geophysical properties as described by Akhter et al. (2016). This process allows the development of a localized, multiple species allometric models to represent a specific vegetation community within a narrower suite of plant functional types. The aims of this study were: (1) to derive total and component wise (leaf, branch, stem and bark) allometric biomass models for the Sal zone of Bangladesh; (2) to measure nutrients $(\mathrm{N}, \mathrm{P}$ and $\mathrm{K})$ and carbon concentration in leaf, branch, stem and bark of the studied tree species; and (3) to compare the model efficiency of frequently used regional and pan-tropical biomass model.

\section{Materials and methods}

\section{Description of the study area}

This study was conducted in the Sal zone of Bangladesh (Fig. 1). This zone comprises 121,000 ha of non-contiguous land scattered across the central and northern part of the country in the Districts of Gazipur, Tangail, Mymensingh, Jamalpur, Comilla, Dinajpur, Thakurgaon, Rangpur and Rajshahi. Soils of this zone are heterogeneous, well drained, acidic and have clayey to fine loamy texture (Hoque et al. 2008). Shorea robusta, locally known as Sal, is the dominant species within the zone in association with Albizia spp., Swietenia spp., Terminalia spp., Azadirachta indica A. Juss. and Adina cordifolia (Roxb.). However, most of the area is heavily degraded due to intense population pressure, resulting in agricultural, industrial developments encroaching into forest areas and a legacy of unregulated or illicit timber extraction (Islam \& Sato 2012). In many areas the dominant Sal trees have been replaced with fast growing timber species (such as Acacia auriculiformis A.Cunn. ex Benth., A. mangium Willd. and Eucalyptus camaldulensis Dehnh.) and horticultural trees (Rahman et al. 2010).

\section{Measurement of biomass}

\section{Sample collection}

Sample trees were harvested from areas of natural Sal forest, woodlots of fast growing species, and wooded homestead areas within the Sal zone. A total of 161 sample trees from 20 species (belonging to 14 families - Tab. 1) were selected in the districts of Tangail and Gazipur during 2016 and 2017. Sample trees were selected purposively, avoiding suppressed or diseases trees or those with broken tops, hollows, or other damages. All sampled trees were within a diameter at breast height (DBH) range of 6 to $38 \mathrm{~cm}$, and total height $(\mathrm{H})$ range of 4 to $29 \mathrm{~m}$, respectively (see Tab. $\mathrm{S} 1$ in Supplementary material).

\section{Biomass measurement}

DBH of the selected trees were measured before felling. The trees were felled as close to ground level as possible and total tree length was measured using a linear tape to representing total height. The felled trees were separated into leaves, small branches (diameter $<7 \mathrm{~cm}$ ), bigger branches (diameter $>7 \mathrm{~cm}$ ) and stem, based on the method described by Picard et al. (2015). The fresh weight of leaves and branches were weighed in the field using a portable digital hanging balance of $100 \mathrm{~kg}$ capacity. The stem was sectioned into suit- 
able size for easy handling and their biomass was measured using a hanging digital balance of $400 \mathrm{~kg}$ capacity. Stem sections (1 $\mathrm{m}$ long) from different positions (base, middle and top) were debarked in the field to get fresh weight proportions of stem and bark to estimate bark and stem wood biomass of the individual sampled trees (Mahmood et al. 2004, 2015). Ten sub-samples $(0.25 \mathrm{~kg})$ of each part (leaf, smaller branch, bark, disk of bigger branches and stem) of individual species were taken randomly from the felled trees and transported to laboratory for further analysis. These sub-samples were oven-dried at 105 ${ }^{\circ} \mathrm{C}$ until a constant weight was achieved to estimate the fresh to oven-dry weight conversion factor. The respective conversion factors were used to estimate the oven-dry weight of individual trees.

\section{Carbon and nutrients ( $\mathrm{N}, \mathrm{P}$ and $\mathrm{K}$ ) in total above-ground biomass (TAGB)}

The oven-dried sub-samples of each part of individual species were grounded and sieved through a 2-mm mesh (Allen 1989). The processed samples were acid digested using Kjeldhal digestion method and the sample extract was analyzed according to Beathgen \& Alley (1989) to determine Nitrogen in plant samples. Tri-acid $\left(\mathrm{HNO}_{3}\right.$, $\mathrm{H}_{2} \mathrm{SO}_{4}$ and $\mathrm{HClO}_{3}$ in 10:1:3 ratio) digestion was adopted to determine phosphorus and potassium in sample extracts (Allen 1989). Phosphorus concentration in sample extracts was measured according to Murphy \& Riley (1962), while a flame photometer (PFP7, Jenway Ltd., UK) was used to measure potassium concentration in sample extracts. Carbon content was measured by the loss of ignition method (Allen 1989). Average and standard error of nutrients ( $\mathrm{N}, \mathrm{P}$ and $\mathrm{K}$ ) and carbon concentration in leaf, branch, stem and bark of sampled tree species were also estimated.

\section{Data analysis}

\section{Allometric equations}

Descriptive statistics of predictors (DBH, $\mathrm{H}$ and WD) and output variables (TAGB, stem, branch and leaf biomass) were calculated. The wood density values of the sampled tree species were collected from Sat$\operatorname{tar}(1981)$. These variables were transformed to natural logarithm (In) to improve the linearity and homoscedasticity. The eight most frequently used pan-tropical or regional biomass allometric equations were tested for the prediction of TAGB (Tab. 2) using $R$ statistical software. Studentized residual analysis was performed to detect the outlier data. Natural logarithm transformation introduced a systematic bias during biomass estimation. Therefore, a correction factor (CF) was calculated for each equation to minimize the systematic bias introduced during the back transformation to biomass value. This correction factor (CF) was multiplied with the exponential factor of Ln biomass value to mini- mize the inherent systematic bias during biomass estimation (Sprugel 1983).

\section{Model selection}

The best fit allometric model was selected based on goodness-of-fit statistics. The model having the lowest Akaike Information Criterion (AIC) and Residual Standard Error (RSE), and the highest Akaike Information Criterion weight (AICW) and coefficient of determination $\left(R^{2}\right)$ values was selected as best fit model (Sileshi 2014, Picard et al. 2015). However, very small difference among the AIC values of models may lead to a false sense of confidence during model selection process. Therefore, AICW was calculated to overcome this confusion and to describe the relative performance of the models (Wagenmakers \& Farrell 2004). AICW was calculated from the following equation (eqn. 1):

$$
A I C w=\frac{\exp \left\{-\frac{1}{2} \Delta i(\text { AIC })\right\}}{\sum_{k=1}^{k} \exp \left\{-\frac{1}{2} \Delta k(A I C)\right\}}
$$

where $\Delta i(A I C)$ is the difference between the model having minimum AIC value and AIC of the individual model.

Test of multicollinearity is important for the models containing identical multiple predictors (Sileshi 2014). Therefore, multicollineary among the predictors of model 2, 3, 4, 6 and 7 were tested using Variance Influential Factor (VIF). Models having $\mathrm{VIF}>5$ indicate the existence of multicollinearity among the predictors (Sileshi 2014). VIF was calculated using the following formula (eqn. 2):

$$
V I F=\frac{S D^{2}(n-1) S E^{2}}{M S R}
$$

where SD is the standard deviation of individual predictor, $\mathrm{SE}$ is the standard error of each predictor, $(n-1)$ is the total degree of freedom for the model, and MSR is the mean square residual.

\begin{tabular}{|c|c|c|c|}
\hline $\begin{array}{l}\text { Model } \\
\text { no. }\end{array}$ & Model & Source & Type \\
\hline 1 & $\ln (B)=a+b \ln (\mathrm{DBH})$ & Brown (1997) & Pan-tropical \\
\hline 2 & $\ln (B)=a+b \ln (\mathrm{DBH})+c \ln (\mathrm{H})$ & Nelson et al. (1999) & Central Amazon \\
\hline 3 & $\begin{array}{l}\ln (B)=a+b \ln (\mathrm{DBH})+c \ln (\mathrm{H})+ \\
\quad d \ln (\mathrm{WD})\end{array}$ & $\begin{array}{l}\text { Nelson et al. (1999), } \\
\text { Chave et al. (2005) }\end{array}$ & $\begin{array}{l}\text { Central Amazon; } \\
\text { Pan-tropical }\end{array}$ \\
\hline 4 & $\begin{array}{l}\ln (B)=a+b \ln (\mathrm{DBH})+c(\ln (\mathrm{DBH}))^{2}+ \\
\quad d(\ln (\mathrm{DBH}))^{3}+e \ln (\mathrm{WD})\end{array}$ & Chave et al. (2005) & Pan-tropical \\
\hline 5 & $\ln (B)=a+b \ln \left(\mathrm{DBH}^{2} \times \mathrm{H} \times \mathrm{WD}\right)$ & $\begin{array}{l}\text { Brown et al. (1989), } \\
\text { Chave et al. (2005), } \\
\text { Chave et al. (2014) }\end{array}$ & Pan-tropical \\
\hline 6 & $\ln (B)=a+b \ln (\mathrm{DBH})+c \ln (\mathrm{WD})$ & Djomo et al. (2010) & Tropical Africa \\
\hline 7 & $\begin{array}{l}\ln (B)=a+b \ln \left(\mathrm{DBH}^{2} \times \mathrm{H}\right)+ \\
\quad c \ln (\mathrm{WD})\end{array}$ & Djomo et al. (2010) & Tropical Africa \\
\hline 8 & $\ln (B)=a+b \ln \left(\mathrm{DBH}^{2} \times \mathrm{H}\right)$ & $\begin{array}{l}\text { Brown et al. (1989), } \\
\text { Djomo et al. (2010) }\end{array}$ & $\begin{array}{l}\text { Pan-tropical; } \\
\text { Tropical Africa }\end{array}$ \\
\hline
\end{tabular}

Tab. 2 - Frequently used pan-tropical and regional allometric equations.

\section{Regional and pan-tropical model} evaluation

Frequently used regional and pan-tropical biomass models were compared with the measured biomass data of the sampled trees of Sal zone in terms of model prediction error (MPE), model efficiency (ME) and root mean square error (RMSE - Mayer \& Butler 1993), which were calculated using the following equations (eqn. 3, eqn. 4, eqn. 5);

$$
\begin{aligned}
& \operatorname{MPE}(\%)=\frac{100}{n} \cdot \sum\left[\frac{(Y p-Y o)}{Y o}\right] \\
& M E=1-\left[\frac{\sum(Y o-Y p)^{2}}{\sum(Y o-\bar{Y})^{2}}\right] \\
& R M S E=100 \cdot \sqrt{\frac{1}{n} \sum_{i=1}^{n}(Y p-Y o)^{2}}
\end{aligned}
$$

where $n$ is the number of trees, $Y p$ is the predicted biomass from model, Yo is the observed biomass in field measurement and $\bar{Y}$ is the mean of the observed biomass. Regression between $Y p$ (in the $X$-axis) and $Y_{0}$ (in the $Y$-axis) was derived for the listed pan-tropical and regional models for TAGB estimation (Tab. 2) and significance of slope $(b=1)$ and intercept $(a=1)$ were also tested in accordance with Piñeiro et al. (2008). This analysis helped to understand graphically the overestimation or underestimation of the predicted biomass value using each model from 1:1 line (Sileshi 2014).

\section{Results}

\section{Model selection}

The mean $\mathrm{DBH}, \mathrm{H}$, and WD of the sample trees were $16.078 \mathrm{~cm}, 13.498 \mathrm{~m}$ and 0.669 $\mathrm{g} \mathrm{cm}^{-3}$, respectively. A total of $1.242 \%$ data was observed as outlier for TAGB. Model 3 $[\ln (B)=\ln (a)+b \ln (\mathrm{DBH})+c \ln (\mathrm{H})+d \ln$ (WD)] of TAGB, stem, bark and branch had lowest AIC (-177.416, -128.402, -18.043 and 247.098) and RSE (0.136, $0.158,0.223$ and 0.508 ); and highest adjusted $\mathrm{R}^{2}$ (0.977, $0.973,0.955$ and 0.756$)$ and AICW (0.918, $0.907,0.614$ and 0.550 ) values compared 
Tab. 3 - Parameter estimates (a-e) and comparison among the allometric models for different components of trees of Sal zone. Models labelled with an asterisk (*) are the best-fit models.

\begin{tabular}{|c|c|c|c|c|c|c|c|c|c|c|c|c|}
\hline $\begin{array}{l}\text { Comp- } \\
\text { onent }\end{array}$ & No. & $a$ & $b$ & c & $d$ & $e$ & Adj- $R^{2}$ & RSE & AIC & $\mathrm{AlCw}$ & CF & VIF \\
\hline \multirow{8}{*}{ 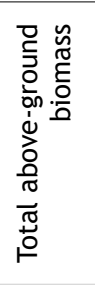 } & 1 & -2.212 & 2.397 & - & - & - & 0.959 & 0.183 & -86.341 & 0.000 & 1.017 & - \\
\hline & 2 & -2.527 & 2.188 & 0.349 & - & - & 0.976 & 0.139 & -172.596 & 0.082 & 1.01 & $b=1.428, c=1.428$ \\
\hline & $3^{*}$ & -2.46 & 2.171 & 0.367 & 0.161 & - & 0.977 & 0.136 & -177.416 & 0.918 & 1.009 & $b=1.214, c=1.497, d=1.055$ \\
\hline & 4 & 3.477 & -3.805 & 2.22 & -0.261 & 0.03 & 0.959 & 0.181 & -83.751 & 0.000 & 1.017 & $b=10560, c=43036, d=11181, e=1.016$ \\
\hline & 5 & -2.071 & 0.844 & - & - & - & 0.932 & 0.236 & -4.028 & 0.000 & 1.028 & - \\
\hline & 6 & -2.204 & 2.397 & 0.016 & - & - & 0.959 & 0.183 & -84.38 & 0.000 & 1.017 & $b=1.006, c=1.006$ \\
\hline & 7 & -2.381 & 0.859 & 0.38 & - & - & 0.941 & 0.22 & -24.429 & 0.000 & 1.025 & $b=1.00, c=1.00$ \\
\hline & 8 & -2.54 & 0.859 & - & - & - & 0.935 & 0.231 & -11.576 & 0.000 & 1.027 & - \\
\hline \multirow{8}{*}{ 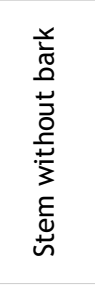 } & 1 & -2.856 & 2.449 & - & - & - & 0.889 & 0.32 & 93.878 & 0.000 & 1.052 & - \\
\hline & 2 & -3.562 & 1.98 & 0.783 & - & - & 0.966 & 0.177 & -94.318 & 0.000 & 1.016 & $b=1.428, c=1.428$ \\
\hline & $3^{*}$ & -3.373 & 1.934 & 0.833 & 0.452 & - & 0.973 & 0.158 & -128.402 & 0.907 & 1.013 & $b=1.367, c=1.497, d=1.055$ \\
\hline & 4 & 1.749 & -2.748 & 1.949 & -0.24 & 0.131 & 0.888 & 0.319 & 98.545 & 0.000 & 1.053 & $b=10560, c=43036, d=11181, e=1.016$ \\
\hline & 5 & -3.079 & 0.911 & - & - & - & 0.965 & 0.179 & -93.176 & 0.000 & 1.016 & - \\
\hline & 6 & -2.793 & 2.445 & 0.122 & - & - & 0.889 & 0.319 & 95.118 & 0.000 & 1.053 & $b=1.006, c=1.006$ \\
\hline & 7 & -3.359 & 0.925 & 0.492 & - & - & 0.972 & 0.162 & -123.849 & 0.093 & 1.013 & $b=1.00, c=1.00$ \\
\hline & 8 & -3.565 & 0.925 & - & - & - & 0.963 & 0.184 & -83.41 & 0.000 & 1.017 & - \\
\hline \multirow{8}{*}{$\begin{array}{l}\text { 憘 } \\
\text { ص }\end{array}$} & 1 & -5.339 & 2.679 & - & - & - & 0.871 & 0.382 & 151.379 & 0.000 & 1.076 & - \\
\hline & 2 & -6.115 & 2.164 & 0.861 & - & - & 0.946 & 0.246 & 11.134 & 0.000 & 1.031 & $b=1.428, c=1.428$ \\
\hline & $3^{*}$ & -5.87 & 2.103 & 0.926 & 0.587 & - & 0.955 & 0.223 & -18.043 & 0.614 & 1.026 & $b=1.671, c=1.497, d=1.055$ \\
\hline & 4 & -5.815 & 3.156 & -0.112 & 0.005 & 0.217 & 0.87 & 0.38 & 155.503 & 0.000 & 1.076 & $b=10560, c=43036, d=11181, e=1.016$ \\
\hline & 5 & -5.606 & 1 & - & - & - & 0.951 & 0.235 & -4.806 & 0.001 & 1.028 & - \\
\hline & 6 & -5.225 & 2.671 & 0.22 & - & - & 0.871 & 0.38 & 151.64 & 0.000 & 1.076 & $b=1.006, c=1.006$ \\
\hline & 7 & -5.856 & 1.012 & 0.625 & - & - & 0.955 & 0.225 & -17.113 & 0.386 & 1.026 & $b=1.00, c=1.00$ \\
\hline & 8 & -6.119 & 1.012 & - & - & - & 0.944 & 0.252 & 16.859 & 0.000 & 1.032 & - \\
\hline \multirow{8}{*}{$\begin{array}{l}\bar{U} \\
\frac{U}{0} \\
\overline{0}\end{array}$} & 1 & -3.628 & 2.348 & - & - & - & 0.704 & 0.563 & 276.164 & 0.000 & 1.172 & - \\
\hline & 2 & -3.007 & 2.761 & -0.69 & - & - & 0.754 & 0.512 & 247.499 & 0.450 & 1.141 & $b=1.428, c=1.428$ \\
\hline & $3^{*}$ & -3.154 & 2.798 & -0.729 & -0.355 & - & 0.756 & 0.508 & 247.098 & 0.550 & 1.14 & $b=1.478, c=1.497, d=1.055$ \\
\hline & 4 & 2.383 & -2.992 & 1.431 & -0.107 & -0.038 & 0.706 & 0.556 & 277.791 & 0.000 & 1.171 & $b=10560, c=43036, d=11181, e=1.016$ \\
\hline & 5 & -2.64 & 0.714 & - & - & - & 0.509 & 0.726 & 357.744 & 0.000 & 1.301 & - \\
\hline & 6 & -3.662 & 2.351 & -0.066 & - & - & 0.702 & 0.563 & 278.092 & 0.000 & 1.173 & $b=1.006, c=1.006$ \\
\hline & 7 & -2.921 & 0.727 & 0.292 & - & - & 0.511 & 0.722 & 357.913 & 0.000 & 1.3 & $b=1.00, c=1.00$ \\
\hline & 8 & -3.044 & 0.728 & - & - & - & 0.511 & 0.724 & 356.77 & 0.000 & 1.299 & - \\
\hline \multirow{8}{*}{ 茜 } & $1^{*}$ & -4.713 & 2.066 & - & - & - & 0.533 & 0.713 & 304.322 & 0.402 & 1.289 & - \\
\hline & 2 & -4.927 & 1.968 & 0.187 & - & - & 0.533 & 0.71 & 305.295 & 0.247 & 1.289 & $b=1.35, c=1.35$ \\
\hline & 3 & -4.826 & 1.936 & 0.226 & 0.278 & - & 0.532 & 0.708 & 306.601 & 0.129 & 1.29 & $b=1.412, c=1.448, d=1.076$ \\
\hline & 4 & -2.24 & -0.072 & 0.583 & -0.046 & 0.185 & 0.525 & 0.711 & 309.671 & 0.028 & 1.295 & $b=9797, c=39949, d=10394, e=1.015$ \\
\hline & 5 & -4.737 & 0.743 & - & - & - & 0.509 & 0.731 & 311.299 & 0.012 & 1.306 & - \\
\hline & 6 & -4.618 & 2.058 & 0.179 & - & - & 0.531 & 0.712 & 306.017 & 0.172 & 1.291 & $b=1.07, c=1.07$ \\
\hline & 7 & -4.883 & 0.75 & 0.531 & - & - & 0.507 & 0.73 & 312.876 & 0.006 & 1.308 & $b=1.00, c=1.00$ \\
\hline & 8 & -5.098 & 0.749 & - & - & - & 0.502 & 0.736 & 313.419 & 0.004 & 1.312 & - \\
\hline
\end{tabular}

Tab. 4 - Carbon concentration (\%) in different parts of sampled species in the Sal zone of Bangladesh.

\begin{tabular}{|c|c|c|c|c|c|}
\hline Species & Leaf & Smaller branch & Bigger branch & Bark & Stem \\
\hline Acacia auriculiformis & $46.87 \pm 0.03$ & $48.77 \pm 0.18$ & $49.73 \pm 0.04$ & $44.93 \pm 0.03$ & $49.75 \pm 0.05$ \\
\hline Aegle marmelos & $50.20 \pm 1.70$ & $56.90 \pm 3.01$ & - & $51.05 \pm 2.58$ & $59.50 \pm 3.99$ \\
\hline Albizia procera & $45.45 \pm 0.65$ & $49.22 \pm 1.08$ & $50.63 \pm 1.50$ & $45.52 \pm 1.30$ & $52.43 \pm 1.58$ \\
\hline Artocarpus heterophyllus & $46.24 \pm 2.28$ & $46.88 \pm 0.78$ & $53.77 \pm 0.81$ & $43.93 \pm 1.56$ & $54.78 \pm 1.59$ \\
\hline Averrhoa carambola & $49.26 \pm 1.36$ & $49.11 \pm 1.51$ & - & $47.48 \pm 0.17$ & $59.23 \pm 1.91$ \\
\hline Citrus grandis & $43.89 \pm 0.37$ & $49.04 \pm 0.25$ & - & $43.22 \pm 1.77$ & $52.79 \pm 1.80$ \\
\hline Elaeocarpus serratus & $57.34 \pm 4.20$ & $54.35 \pm 1.64$ & $54.45 \pm 0.33$ & $60.21 \pm 2.64$ & $56.66 \pm 0.41$ \\
\hline Grewia microcosm & $45.04 \pm 0.53$ & $52.75 \pm 0.55$ & $54.25 \pm 1.11$ & $53.59 \pm 1.69$ & $52.86 \pm 1.04$ \\
\hline Litchi chinensis & $44.33 \pm 0.87$ & $55.44 \pm 0.97$ & $53.65 \pm 2.36$ & $44.34 \pm 2.34$ & $53.50 \pm 1.32$ \\
\hline Mangifera indica & $57.96 \pm 2.89$ & $51.74 \pm 1.86$ & $56.13 \pm 1.78$ & $48.88 \pm 1.00$ & $55.86 \pm 0.29$ \\
\hline Phyllanthus emblica & $55.95 \pm 2.23$ & $49.66 \pm 1.64$ & $53.51 \pm 0.17$ & $66.31 \pm 2.51$ & $53.67 \pm 1.54$ \\
\hline Psidium guajava & $50.59 \pm 1.87$ & $48.02 \pm 1.29$ & - & $48.88 \pm 0.70$ & $51.00 \pm 0.40$ \\
\hline Shorea robusta & $49.74 \pm 0.97$ & $43.89 \pm 6.68$ & $50.94 \pm 0.61$ & $52.85 \pm 2.16$ & $56.24 \pm 2.21$ \\
\hline Spondias pinnata & - & $44.71 \pm 0.68$ & $48.86 \pm 0.90$ & $50.17 \pm 2.18$ & $53.53 \pm 1.48$ \\
\hline Syzygium cumini & $50.15 \pm 0.39$ & $46.86 \pm 0.93$ & $55.37 \pm 1.40$ & $50.59 \pm 0.73$ & $52.72 \pm 0.08$ \\
\hline Tectona grandis & $41.80 \pm 0.92$ & $49.07 \pm 0.44$ & - & $46.82 \pm 1.44$ & $57.77 \pm 1.30$ \\
\hline Terminalia arjuna & $47.88 \pm 1.03$ & $56.89 \pm 3.25$ & $56.61 \pm 0.32$ & $48.16 \pm 0.98$ & $52.41 \pm 1.64$ \\
\hline Terminalia bellirica & $59.25 \pm 1.67$ & $55.26 \pm 1.88$ & $55.24 \pm 3.63$ & $44.73 \pm 1.09$ & $58.23 \pm 3.38$ \\
\hline Zanthoxylum rhetsa & - & $50.22 \pm 2.66$ & $53.40 \pm 1.05$ & $55.21 \pm 2.68$ & $53.55 \pm 1.05$ \\
\hline Ziziphus mauritiana & $47.50 \pm 4.01$ & $52.52 \pm 0.39$ & $52.31 \pm 1.96$ & $50.47 \pm 4.03$ & $54.73 \pm 2.02$ \\
\hline
\end{tabular}


Tab. 5 - Comparison of the frequently used regional and pan-tropical biomass models.

\begin{tabular}{|c|c|c|c|c|c|c|c|c|}
\hline No & Source & Equation & Type & $\mathrm{n}$ & $\mathbf{R}^{2}$ & MPE (\%) & ME & RMSE \\
\hline 1 & Brown 1997 (Moist) & $B=\exp (-2.134+2.5430 \ln (\mathrm{DBH}))$ & Pan-tropical & 170 & - & 63.556 & -0.093 & 10666.328 \\
\hline 3 & Nelson et al. 1999 & $\begin{array}{l}\ln (B)=-1.8985+2.1569 \ln (\mathrm{DBH})+0.3888 \\
\quad \ln (H)+0.7218 \ln (W D)\end{array}$ & & 132 & 0.991 & 42.958 & 0.636 & 6159.087 \\
\hline 4 & Chave et & $\begin{array}{r}B=W D \times \exp (-1.499+2.1 \\
0.207(\ln (D B H))^{2}-0.028\end{array}$ & Pan-tropical & 1808 & 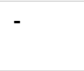 & & -1.878 & 17312.340 \\
\hline \multirow[t]{3}{*}{5} & Brown et al. & $B=\exp \left(-2.4090+0.9522 \ln \left(D^{2} H^{2} \times H \times W D\right)\right)$ & & 94 & 0.99 & & -0.16 & 597 \\
\hline & Chave et al. 2005 & $B=\exp \left(-2.977+\ln \left(\mathrm{DBH}^{2} \times \mathrm{H} \times \mathrm{WD}\right)\right)$ & Pan-tropical & 1505 & - & 35.480 & 0.404 & 7877.611 \\
\hline & Chave et al. 2014 & $B=\exp \left(-2.6986+0.976 \ln \left(\mathrm{DBH}^{2} \times \mathrm{H} \times \mathrm{WD}\right)\right)$ & Pan-tropical & 4004 & - & 48.892 & 0.184 & 9217.913 \\
\hline \multirow[t]{2}{*}{8} & Brown et al. 1989 & $B=\exp \left(-3.1141+0.9719 \ln \left(\mathrm{DBH}^{2} \times \mathrm{H}\right)\right)$ & Pan-tropical & 168 & 0. & 42.676 & 0.376 & 8057.775 \\
\hline & Djomo et al. 2010 & $\ln (B)=-3.2249+0.9885 \ln \left(\mathrm{DBH}^{2} \times \mathrm{H}\right)$ & Tropical Africa & 274 & 0.971 & 46.016 & 0.228 & 8964.925 \\
\hline
\end{tabular}

to other models. Model 4 of TAGB, stem, bark, branch and leaf has shown VIF $>5$ for its predictors compared to other models, which indicated multicollinearity among the identical independent variable (Tab. 3). Therefore, model 3 has appeared as best fit for estimating TAGB, stem, bark and branch biomass for the Sal zone and indicates that inclusion of wood density as predictor has improved the model accuracy. For leaf estimates, model $1[\ln (B)=\ln (a)+$ $b$ In (DBH)] is the best model considering the AIC, AICW and adjusted $\mathrm{R}^{2}$ values (Tab. 3).

Nutrients (N, P and $K)$ and carbon in tree components

Nutrients ( $\mathrm{N}, \mathrm{P}$, and $\mathrm{K}$ ) concentration were found to vary among the tree components and species. However, comparatively higher concentration of nitrogen (1.76 to $4.06 \%$ ), phosphorus (0.02 to $0.54 \%$ ) and potassium ( 0.28 to 3.10 ) were observed in leaves, while the lowest concentration was observed in woody components, especially the stem (Tab. S2 in Supplementary material). Conversely, comparatively higher concentration of carbon was observed in woody components of tree-like stems and larger branches. The ranges of carbon concentration in stems and bigger branches of the represented species was 48.86 to $56.61 \%$ and 49.75 to $59.23 \%$, respectively. Moreover, species-specific variation in carbon concentration was also observed among individual species (Tab. 4).

\section{TAGB model evaluation}

The comparison among the eight regional and pan-tropical biomass models has demonstrated that model 3 of Chave et al. (2005) contained first lowest MPE (35.480\%) and RMSE (7877.611) followed by model 8 (moist) of Brown et al. (1989 Tab. 5). Visualization of the observed and predicted biomass has demonstrated deviation in biomass estimation from the line of significance of slope $(b=1)$ and intercept $(a=1)$, which indicates that all the regional and pan-tropical biomass models overestimated the biomass of the sampled trees of the Sal zone (Fig. 2).

\section{Discussion}

The use of allometric models presents a
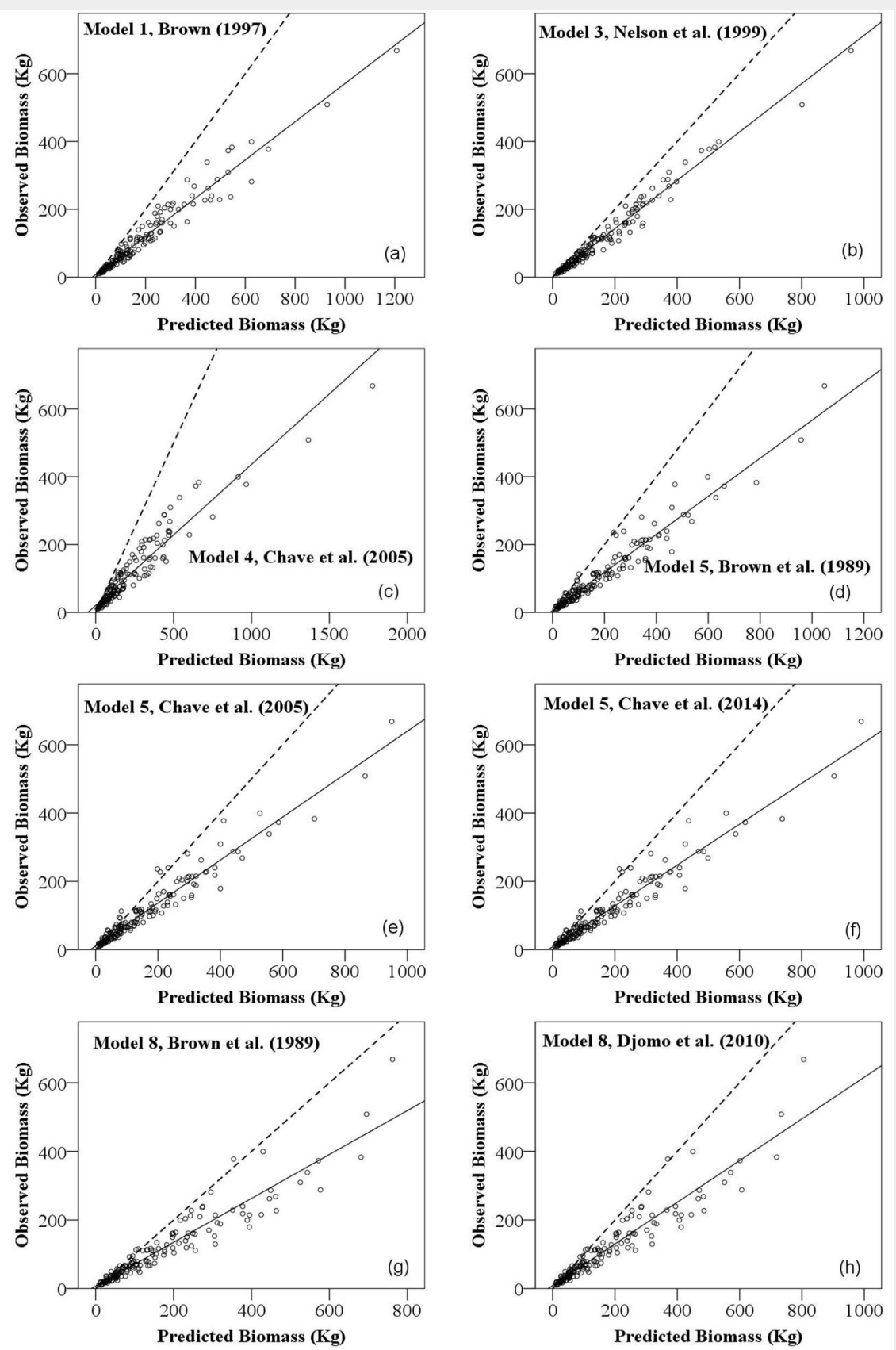

Fig. 2 - Regression between observed and predicted values of frequently used regional and pan-tropical biomass models. Solid line is the regression line and broken line is the significance of slope $(b=1)$ and intercept $(a=1)$. (a): Model 1 (Brown 1997); (b): Model 3 (Nelson et al. 1999); (c): Model 4 (Chave et al. 2005); (d): Model 5 (Brown et al. 1989); (e): Model 5 (Chave et al. 2005); (f): Model 5 (Chave et al. 2014); (g): Model 8 (Brown et al. 1989); (h): Model 8 (Djomo et al. 2010). 
source of uncertainty in biomass estimation (Nam et al. 2016), which can be minimized through a process of selection and critical analysis of the parameters used (Mahmood et al. 2016). Model accuracy and the inclusion of predictor(s) are important considerations when selecting the best fit model (Sileshi 2014). In our study, we have included 20 species with wood density ranging from 0.492 to $0.854 \mathrm{~g} \mathrm{~cm}^{-3}$ and a model with $\mathrm{DBH}, \mathrm{H}$ and WD as identical predictors appeared as the best fit com pared to other models, except leaf (Tab. 3). Several other studies have also demonstrated that multi-species allometric biomass models using DBH, $\mathrm{H}$ and WD as iden tical predictors resulted in accurate biomass estimation (Nelson et al. 1999, Chave et al. 2005, 2014, Djomo et al. 2010).

Estimates of nutrient and carbon stock in trees is crucial to understand nutrient cycling and budgeting, which is important to maintain forest productivity (Binkley 1986, Mahmood 2014). This study has shown that differences are evident in nutrient and carbon concentration across tree components and species, and this is related to the characteristics of nutrients, stage of growth (sapling and tree) and availability to plants under various environmental conditions (Binkley 1986, Marschner 1995, Mahmood 2004). Nitrogen is the major component of amino acid, enzymes, nucleic acid, chlorophyll and alkaloid and consequently a higher content is observed in photosynthetic tissue. Phosphorus is most abundant in meristematic tissue (Mayer \& Butler 1993). While potassium is highly mobile and found to accumulate in physiologically active tis sue, carbon is found to accumulate in the structural components of plants (Marschner 1995). The above physiological function and mobility nature of $\mathrm{N}, \mathrm{P}, \mathrm{K}$ and $\mathrm{C}$ may lead to a higher concentration of nutrients in leaves and higher carbon concentration in branch and stem (Mahmood 2004).

The observed TAGB of sampled trees were compared with estimated TAGB from the frequently used regional and pan-tropical models. Model 4 by Chave et al. (2005) and model 5 by Brown et al. (1989) showed the higher prediction error $(65.82 \%$ to 85.508) and resulted in a higher overestimation. Similarly, the pan-tropical model 5 of Chave et al. (2005) with second higher model efficiency (0.404) also showed the lowest model prediction error (35.48\%) in predicting the TAGB for the studies samples. This has implications for the estimation of forest biomass across broad-scales as these models are a commonly used op tion, particularly in developing countries for which they are relevant, where they may be applied under programmes such as REDD+ (Gibbs et al. 2007, Koch 2010). As this process is fundamentally based on estimation, allometric models will always present some level of error. The quantum of that error will determine the extent to which our understanding of the truth is distorted and subsequently influence how we understand the impacts of deforestation and environmental degradation resulting from forest disturbance potentially driven by climate change (Kumar \& Mutanga 2017). Therefore, the development of improved allometric models, their validation and comparison with the existing pantropical and regional models to assess their uncertainty and suitability at local scale is a prudent step in forest biomass estimation (Sileshi 2014, Nam et al. 2016). Indeed, there remains numerous examples where biomass estimation using pan-tropical and regional models produce a higher bias compared to those from locally developed models, for instance the biomass study of Kalimantan (Basuki et al. 2009), Sarawak (Kenzo et al. 2009), Columbia (Alvarez et al. 2012, Ngomanda et al. 2014), Indonesia (Manuri et al. 2014, Maulana et al. 2016), and Vietnam (Nam et al. 2016). The context provided by these studies and the results presented herein demonstrate that at present, our derived model will more accurately estimate the TAGB and biomass of other components (stem, bark, branch and leaf) for the Sal zone of Bangladesh.

\section{Conclusion}

Regional and pan-tropical allometric models offer methodological efficiencies for biomass estimation compared to those developed for individual species at specific locations. However, they have the potential to misrepresent local, species- or community-specific variations and anomalies, and therefore can lead to increased error. The use of pan-tropical and regional models should therefore be scrutinized with respect to the source of sampling used to develop the model against local forest variation, before they are widely applied. The results of this study demonstrate that the development of local models derived from an appropriate sample of representative species can greatly improve the estimation of TAGB, as well as Carbon, Nitrogen, Phosphorus, and Potassium in TAGB. In summary, the best fit models presented in this study can provide greater confidence when estimating biomass in the Sal zone of Bangladesh.

\section{Acknowledgements}

We greatly acknowledge the financial support of Food and Agriculture Organization of the United Nations (FAO) through GCP/BGD/058/USA (LOA Code: FAOBGDLO A 2017-008) to accomplish the field and laboratory work. We would like to thank Tangail Forest Division and Dhaka Forest Division and Forestry and Wood Technology Discipline, Khulna University (Bangladesh) for their logistic supports during the field and laboratory analysis.

\section{References}

Akhter M, Jalal R, Costello L, Rahman L, Tasnuva $U$ (2016). Zoning for tree and forest assessment in Bangladesh. Bangladesh Forest Department and Food and Agricultural Organization of the
United Nations, Dhaka, Bangladesh, pp. 36. Allen SE (1989). Chemical analysis of ecological materials. Blackwell Scientific Publications, Oxford, UK, pp. 565.

Alvarez E, Rodríguez L, Duque A, Saldarriaga J, Cabrera K, De Las Salas G, Del Valle I, Lema A, Moreno F, Orrego S (2012). Tree above-ground biomass allometries for carbon stocks estimation in the natural forests of Colombia. Forest Ecology and Management 267: 297-308. - doi: 10.1016/j.foreco.2011.12.013

Basuki TM, Van Laake PE, Skidmore AK, Hussin YA (2009). Allometric equations for estimating the above-ground biomass in tropical lowland Dipterocarp forests. Forest Ecology and Management 257: 1684-1694. - doi: 10.1016/j.foreco. 2009.01.027

Beathgen WE, Alley MM (1989). A manual colorimetric procedure for measuring ammonium $\mathrm{Ni}$ trogen in soil and plant Kjeldahl digests. Soil Science and Plant Analysis 20 (9-10): 961-969. doi: $10.1080 / 00103628909368129$

BFD (2016). Field instructions for the Bangladesh forest inventory. Bangladesh Forest Department (BFD) and Food and Agricultural Organization of the United Nations (FAO), Dhaka, Bangladesh, pp. 137.

Binkley D (1986). Forest nutrition management. John Wiley and Sons, New York, USA, pp. 290. [online] URL: http://books.google.com/books? $\mathrm{id}=\mathrm{J} 4 \mathrm{NNO} 8 \mathrm{SbS}-\mathrm{YC}$

Brown S, Gillespie AJR, Lugo AE (1989). Biomass estimation method for tropical forests with applications to forest inventory data. Forest Science 35: 881-902.

Brown S, Lugo AE (1992). Above ground biomass estimates for tropical moist forests of the Brazilian Amazon. Interciencia 17: 8-18.

Brown S (1997). Estimating biomass and biomass change of tropical forests: a primer. FAO Forestry Paper no. 134, Rome, Italy, pp. 55. [online] URL: http://books.google.com/books?id=J4NNo 8SbS-YC

Chave J, Andalo C, Brown S, Cairns MA, Chambers JQ, Eamus D, Fölster H, Fromard F, Higuchi $\mathrm{N}$, Kira T, Lescure JP, Nelson BW, Ogawa $\mathrm{H}$, Puig H, Riera B, Yamakura T (2005). Tree allometry and improved estimation of carbon stocks and balance in tropical forests. Oecologia 145: 87-99. - doi: 10.1007/s00442-005-0100-x

Chave J, Réjou-Méchain $M$, Búrquez $A$, Chidumayo E, Colgan MS, Delitti WB, Duque A, Eid T, Fearnside PM, Goodman RC, Henry M, Martínez-Yrízar A, Mugasha WA, Muller-Landau HC, Mencuccini M, Nelson BW, Ngomanda A, Nogueira EM, Ortiz-Malavassi E, Pélissier R, Ploton $P$, Ryan CM, Saldarriaga JG, Vieilledent G (2014). Improved allometric models to estimate the aboveground biomass of tropical trees. Global Change Biology 10 (10): 3177-3190. - doi: 10.1111/ gcb.12629

Djomo AN, Ibrahimab A, Saborowskic J, Gravenhorst $G$ (2010). Allometric equations for biomass estimations in Cameroon and pan moist tropical equations including biomass data from Africa. Forest Ecology and Management 260: 1873-1885. - doi: 10.1016/j.foreco.2010.08.034

FD (2007). National forest and tree resources assessment 2005-2007 Bangladesh. Bangladesh Forest Department (BFD), Dhaka, Bangladesh, pp. 118. 
FD (2017). National and sub-national forest inventory. Web site. [online] URL: http://www. bforest.gov.bd/site/page/1b2664a5-boa6-445b9d56-c4a85b8434e2/National-and-sub-nationalForest-inventory

Gibbs HK, Brown S, Niles JO, Foley JA (2007). Monitoring and estimating tropical forest carbon stocks: making REDD a reality. Environmental Research Letter 2: 1-13. [online] URL: http://iopscience.iop.org/article/10.1088/1748-9 326/2/4/045023/meta

Hoque AE, Nazrul-Islam AKM, Imamul Huq SM (2008). Seasonal variation of edaphic features of Madhupur Sal forest, Bangladesh. Ecoprint 15: 7-14. - doi: 10.3126/eco.v15io.1936

Iftekhar MS, Saenger P (2008). Vegetation dynamics in the Bangladesh Sundarbans mangroves: a review of forest inventories. Wetlands Ecology and Management 6: 291-312. doi: 10.1007/s11273-007-9063-5

Islam KK, Sato N (2012). Deforestation, land conversion and illegal logging in Bangladesh: the case of the Sal (Shorea robusta) forest. iForest 5: 171-178. - doi: 10.3832/iforo578-005

Kenzo T, Furutani R, Hattori D, Kendawang JJ, Tanaka S, Sakurai K, Ninomiya I (2009). Allometric equations for accurate estimation of above-ground biomass in logged-over tropical rainforests in Sarawak, Malaysia. Journal of Forest Research 14: 365-372. - doi: 10.1007/s1031 0-009-0149-1

Ketterings QM, Coe R, Noordwijk MV, Amagau Y, Palm CA (2001). Reducing uncertainty in the use of allometric biomass equations for predicting above-ground tree biomass in mixed secondary forest. Forest Ecology and Management 146: 199-209. - doi: 10.1016/S0378-1127(00) 00460-6

Koch B (2010). Status and future of laser scanning, synthetic aperture radar and hyperspectral remote sensing data for forest biomass assessment. ISPRS Journal of Photogrammetry and Remote Sensing 65: 581-590. - doi: 10.1016/ j.isprsjprs.2010.09.001

Komiyama A, Poungparn S, Kato S (2005). Common allometric equations for estimating the tree weight of mangroves. Journal of Tropical Ecology 21: 471-477. - doi: 10.1017/S0266467405 002476

Kumar L, Mutanga O (2017). Remote sensing of above-ground biomass. Remote Sensing 9: 935. - doi: $10.3390 /$ rs9090935

Litton CM (2008). Allometric models for predicting aboveground biomass in two widespread woody plants in Hawaii. Biotropica 40 (3): 313320. - doi: 10.1111/j.1744-7429.2007.00383.x

Mahmood H (2004). Biomass, litter production and selected nutrients in Bruguiera parviflora (Roxb.) Wight and Arn. dominated mangrove forest ecosystem at Kuala Selangor, Malaysia. PhD thesis, Biology Department, University Putra Malaysia, Serdang, Malaysia, pp. 333. [online] URL: http://psasir.upm.edu.my/id/eprint/3 95/1/549764_fs_2004_16_abstrak_je_dh_pdf_ .pdf

Mahmood H, Saberi O, Japar Sidik B, Misri K, Rajagopal S (2004). Allometric relationships for estimating above and below-ground biomass of saplings and trees of Bruguiera parviflora (Wight and Arnold). Malaysian Applied Biology 33 (1): 37-45.

Mahmood H, Saberi O, Japar Sidik B, Misri K (2008). Net primary productivity of Bruguiera parviflora (Wight and Arn.) dominated mangrove forest at Kuala Selangor, Malaysia. Forest Ecology and Management 255: 179-182. doi: 10.1016/j.foreco.2007.09.011

Mahmood H (2014). Carbon pools and fluxes in Bruguiera parviflora dominated naturally growing mangrove forest of Peninsular Malaysia. Wetland Ecology and Management 22 (1): 15-23. doi: 10.1007/s11273-013-9318-2

Mahmood H, Siddique MRH, Saha S, Abdullah SMR (2015). Allometric models for biomass, nutrients and carbon stock in Excoecaria agallocha of the Sundarbans, Bangladesh. Wetlands Ecology and Management 23 (4): 765-774. - doi: 10.1007/s11273-015-9419-1

Mahmood H, Siddique MRH, Akhter M (2016). A critical review and database of biomass and volume allometric equation for trees and shrubs of Bangladesh. IOP Conference Series, Earth and Environmental Science 39: 012057. doi: 10.1088/1755-1315/39/1/012057

Manuri S, Brack C, Nugroho NP, Hergoualc'h K, Novita N, Dotzauer H, Verchot L, Putra CAS, Widyasari $E$ (2014). Tree biomass equations for tropical peat swamp forest ecosystems in Indonesia. Forest Ecology and Management 334: 241-253. - doi: 10.1016/j.foreco.2014.08.031

Marschner H (1995). Mineral nutrition of higher plants. Academic Press, New York, USA, pp. 889.

Maulana SI, Wibisono Y, Utomo S (2016). Development of local allometric equation to estimate total aboveground biomass in Papua tropical forest. Indonesian Journal of Forest Research 3 (2): 107-118. - doi: 10.20886/ijfr.2016. 3.2.107-118

Mayer D, Butler D (1993). Statistical validation. Ecological Modeling 68 (1): 21-32. - doi: 10.1016/ 0304-3800(93)90105-2

Murphy J, Riley JP (1962). A modified single solution method for the determination of phosphate in natural waters. Analytica Chimica Acta 27: 31-36. - doi: 10.1016/S0003-2670(00)88444-5 Nam VT, Van Kuijk M, Anten NPR (2016). Allometric equations for aboveground and belowground biomass estimations in an evergreen forest in Vietnam. PLoS ONE 11 (6): e0156827. doi: 10.1371/journal.pone.0156827

Nelson BW, Mesquita R, Pereira JLG, Souza SGAD, Batista GT, Couto LB (1999). Allometric regressions for improved estimate of secondary forest biomass in the central Amazon. Forest Ecology and Management 117: 149-167. doi: 10.1016/S0378-1127(98)00475-7

Ngomanda A, Engone Obiang NL, Lebamba J,
Moundounga Mavouroulou Q, Gomat H, Mankou GS, Loumeto J, Midoko Iponga D, Kossi Ditsouga F, Zinga Koumba R (2014). Site-specific versus pantropical allometric equations: which option to estimate the biomass of a moist central African forest? Forest Ecology and Management 312: 1-9. - doi: 10.1016/j.foreco.2013.10.029 Picard N, Rutishauser E, Ploton P, Ngomanda A, Henry M (2015). Should tree biomass allometry be restricted to power models? Forest Ecology and Management 353: 156-163. - doi: 10.1016/j. foreco.2015.05.035

Piñeiro G, Perelman S, Guerschman JP, Paruelo JM (2008). How to evaluate models: observed vs. predicted or predicted vs. observed. Ecological Modeling 216: 316-322. - doi: 10.1016/j.ecol model.2008.05.006

Rahman MM, Motiur MR, Guogang Z, Islam KS (2010). A review of the present threats to tropical moist deciduous Sal (Shorea robusta) forest ecosystem of central Bangladesh. Tropical Conservation Science 3 (1): 90-102. - doi: 10.1177/194 008291000300108

Rahman MM, Khan MNI, Hoque AKF, Ahmed I (2015). Carbon stock in the Sundarbans mangrove forest: spatial variations in vegetation types and salinity zones. Wetlands Ecology and Management 23: 269-283. - doi: 10.1007/s11273014-9379-x

Sattar MA (1981). Some physical properties of 116 Bangladeshi timbers. Bulletin no. 7, Wood seasoning series, Forest Research Institute, Chittagong, Bangladesh, pp. 15. [online] URL: http://www.cabdirect.org/cabdirect/abstract/19 840689908

Sileshi GW (2014). A critical review of forest biomass estimation models, common mistakes and corrective measures. Forest Ecology and Management 329: 237-254. - doi: 10.1016/j.forec 0.2014 .06 .026

Sprugel DG (1983). Correcting for bias in logtransformed allometric equations. Ecology 64 (1): 209-210. - doi: 10.2307/1937343

Van Breugel M, Ransijn J, Craven D, Bongers F, Hall JS (2011). Estimating carbon stock in secondary forests: decisions and uncertainties associated with allometric biomass models. Forest Ecology and Management 262: 1648-1657. doi: 10.1016/j.foreco.2011.07.018

Wagenmakers EJ, Farrell S (2004). AIC model selection using Akaike weights. Psychonomic Bulletin and Review 11 (1): 192-196. - doi: 10.3758/BF 03206482

\section{Supplementary Material}

Tab. S1 - Observed biomass data of sampled trees of the Sal zone of Bangladesh.

Tab. S2 - Nutrients (N, P and K) concentration in different parts of sample tree species of the Sal zone of Bangladesh.

Link:Mahmood_2758@supplo01.pdf 